\title{
Institutionally Produced ESP Course Implications for Professional Competence Development
}

\author{
Dzhamila Godina ${ }^{1 *}$, Irina Oblovatskaya ${ }^{2}$, Elena Ulitko $^{3}$, Olga Danko $^{3}$, and Irina Yaroslavskaya ${ }^{3}$ \\ ${ }^{1}$ Department of Foreign Languages №1, Plekhanov Russian University of Economics, 117997, 36 Stremyannyi per., Moscow, \\ Russia \\ ${ }^{2}$ Department of Foreign Languages №2, Plekhanov Russian University of Economics, 117997, 36 Stremyannyi per., Moscow, \\ Russia \\ ${ }^{3}$ Department of Foreign Languages №3, Plekhanov Russian University of Economics, 117997, 36 Stremyannyi per., Moscow, \\ Russia
}

\begin{abstract}
The article deals with institutionally developed ESP (English for Specific Purposes) courses, one of the predominant and progressive language teaching approaches in tertiary education, as it is focused on the specific and profession-related needs of students. The paper studies the role of needs analysis and material selection, later adaptation according to particular specialty student requirements, changes of business environment and current demands for English language skills. The implication of the study results in that ESP courses should be more attuned to students' needs targeting productive skills, specialized vocabulary, language functions and intercultural competence. The study also discusses the ways and methods, which can increase professional competence development in the context of the multiprofessional environment of a modern economic university experiencing constant changes due to internationalization.
\end{abstract}

\section{Introduction}

A noticeable trend in English language teaching and learning is the paramount importance of English for Specific Purposes in tertiary education dictated by internationalization and globalization of higher education. This tendency is driven by some reasons: first, learners' needs of language skills in a particular domain, occupation or vocation in order to perform particular job-related functions; second, the globalized world and international trade have set demands for peculiar language skills. 'Learners know specifically why they are learning a language and it is the awareness of the need that ESP distinguishes for' state Hutchinson and Waters [1].

It is noteworthy that English has been the main language of international communication, which has become an integral part of most modern professions. To be able to communicate successfully in English, students of different professions are thus taught ESP, whose overriding characteristics are 'the sense of purpose and the sense of vocation'. These characteristics predominantly focus on what students will need in their working environments, or, as Harding puts it: 'in ESP English for Specific Purposes - the purpose for learning the language is paramount and relates directly to what the learner needs to do in their vocation or job' [2].

As ESP approach is presumably student-centered, then learners' needs analysis is a key point in the course designing. Their needs are undergoing a constant change and improvement due to various socio-economic situations in the labour market and global networking. 'In order to help them succeed in their foreign studies, teachers of English for Specific Purposes (ESP) try to meet their language needs. In fact, identifying their specific language needs is a basic characteristic which distinguishes ESP from general English teaching' claims Klimova [3].

\section{Methods and Materials}

Not long ago, students studying for different professions were taught mainly General English, which was not always very helpful when applied in real-life situations of different areas of specialism, such as engineering, tourism, marketing and logistics, science and technology, medicine, and so on. With time, developments in language theory indicated the need to pay more attention to individual learners' needs. This realization together with a growing demand for English courses tailored to students' specific needs led to the emergence of English for Specific Purposes (ESP) in the late 1960s. This area proved to be fertile ground, and so ESP has undergone rapid developments in recent decades. 'ESP, with its duel focus on language and content, was driven by common factors, including the omnipresence of English as the international language of

* Corresponding author: dzhamilagodina@mail.ru 
communication and the demands of world economy' points out Tzoannopoulou [4].

According to Hutchinson and Waters ESP can be further subdivided into "two main types of ESP differentiated according to whether the learner requires English for academic study (EAP: English for Academic Purposes) or for work/training (EOP/EVP/VESL: English for Occupational Purposes/English for Vocational Purposes/Vocational English as a Second Language)' [1]. We need to emphasize that this distinction is not clear-cut because very often the language learnt for immediate use in a study environment will be used later when the student takes up, or returns to a job. Accordingly, English in finance could be categorized as both EAP and EOP because students use it in their study environment as well as in their jobs.

Another group of scholars, among them Aylazyana and Obdalova, Vičič and Minasyan, in the ESP course designing process emphasize the utmost importance of 'competencies such as communicative skills for making contacts worldwide, working in groups or international teams, ability to argue effectively, ethical liability of decision-making, flexibility and social experience, create a lasting ground for professional and cultural development of specialists' [5], 'the target audience and their goals, as well as their motivation to learn the language' [6], and 'the materials selected should not be solely or primarily subject specific and what the most appropriate ratio of general materials to subject-specific materials is to be considered' [7].

\section{Discussion}

\subsection{Specifications of ESP courses}

ESP courses are distinguished by three common features: authentic material, purpose-related orientation and self-direction.

By authenticity is meant genuine communication through authentic texts or videos which are produced by real speakers or writers for a real audience aiming to convey a real message [3]. Authentic materials are widely used by ESP course designers and have proved to be effective teaching resources as they enable learners to face the professional language they will deal with in the real labour world, thus react to it with confidence and competence. Under current education regulations, students in tertiary education have enough level of language proficiency to deal with the complexity and authenticity of non-adapted materials which increase the learners' motivation and lesson engagement.

Purpose-related orientation is another key feature of ESP courses and it refers to simulation of communicative tasks. These tasks are required for further real job-related settings, such as simulation of a conference, negotiation, job interview, telephoning, etc.

And by self-direction is meant turning learners into users which is a crucial aspect for the effectiveness and success of ESP courses. Self-direction occurs when learners have a certain degree of freedom and autonomy to make decisions on what, when and how to learn. This feature is aligned with autonomous learning approach where there exists high-level rapport between learners and teachers, and learners take control over their learning.

\subsection{Core constituents of ESP course designing}

Largely, ESP courses encompass the following key stages: needs analysis, course design (syllabus), materials selection (adaptation and production), course delivery, learning and assessment.

Needs analysis as a preliminary stage for any ESP course plays undoubtedly crucial role, as it helps to establish learners' purposes, present language level, feasible knowledge gaps and desired outcomes. And Strevens agrees 'ESP instruction is derived to meet learners' needs' [8]. Thus, after analysing learner needs and setting objectives for the course, the ESP educator has to select materials that will help both the teacher and students achieve the course objectives. These materials should also relate closely to the learners' specific skills and content needs, which is an important precondition for full exploitation of the materials, as well as the learners' motivation. A similar argumentation is given by Benaventa and Sánchez-Reyesb, who assert that 'Needs analysis revealed the professional contexts in which trainees would be required to use English. Target situations were identified and became centre stage in syllabus and materials design' [9].

Hereafter, it is due to mention that some scholars distinguish objective/perceived or subjective/felt needs. Objective needs refer to all factual information about the learners: language proficiency, language difficulties and the use of language in authentic situations. Subjective needs include cognitive and affective needs of learners: confidence, attitudes and expectations. Consequently, a careful and extensive needs analysis is the cornerstone of ESP course design as it helps to reveal learners' necessities, establish knowledge gaps and expectations, i.e. it defines what to teach and how to teach, which are essential for setting the goals or objectives of ESP courses. The further help of needs analysis is the correct choice of materials to be taught.

There may be diverse ways of carrying on needs analysis, like interviews, questionnaires, observations, pro-forma tests, work shadowing, discussions, telephone conversations, etc. What refers to tertiary education, learners' needs are identified and formulated by the institution faculty relevant to their study area, specialization and likely language proficiency, later turning them into syllabus.

Another key factor of ESP course design is the selection and evaluation of teaching and learning materials, which vary from handy textbooks, supplementary materials, and online resources to tailormade institutional ones. The choice of teaching materials is of paramount importance as they should suit the professional target needs of learners, be appropriate for present labour world, and closely related to learners' needs and motivation. 'Materials provide a stimulus to 
learning. Good materials do not teach: they encourage learners to learn' [1]. Moreover, the selected materials should first develop intercultural and interpersonal skills, rather than focus only on lexical and grammatical aspects. To act effectively and successfully in current globalised economic environment is assured by highlevel cross-cultural communication competence and good rapport.

Therefore, ESP materials undergo ongoing evaluation: pre-use, when the future and potential performance of the textbook is examined; in-use; assessing the currently used textbook; post-use; which enables to improve or replace the given teaching materials. In our case, in tertiary education, the evaluation process is a collaborative activity where the feedback of learners and their tangible progress is considered, and the evaluation of the faculty, who are responsible for the syllabus design and course delivery. Accordingly, Basturkmen outlines four areas of curriculum development: 'focusing on the course, determining the course content, developing materials, and evaluating courses and materials' [10].

\subsection{ESP material selection \& production criteria}

It is due to point out that the selection, adaptation or production of ESP materials should above all depend on learners needs in relation to their future professions, should include relevant topics, tasks and approaches that practice the target skills area. The impact of selected materials on the entire ESP course is demonstrated in three levels by Ellis and Johnson [11]:

- It determines the type of language the learners will be exposed to, and what they will learn in terms of vocabulary, structures and functions.

- It has implications for methods and techniques of teaching and learning.

- It is an essential component for being relevant and motivating.

The above-mentioned ideas considering ESP materials selection, adaptation or production, and ongoing evaluation can be summarized in the following way:

- Relevant: materials should be adequate and appropriate for learners' age, language level, study area and future vocation.

- Diverse: they should include a range of activities and teaching techniques focused on specific language structures, vocabulary, and skills.

- Acceptable: they should address cultural diversity and nurture respect and tolerance towards other cultures since learners can act as intercultural speakers.

- Motivating: they should cover authentic, challenging and motivating content in order to increase students' interest, effectiveness and commitment to learn.

- Personalised: the materials should meet the requirements of all learners - abled and disabled, from intermediate to advanced levels, extroverts and introverts, who may opt for studying individually at home or in-class.

\section{Results}

In this article, an attempt is made to highlight mostly the benefits and drawbacks of the institutionally derived or teacher derived materials for tertiary education as currently we witness a permanent surge in the quantity of in-company produced teaching materials. Relying on our own experience and survey carried on among second and third grade students a number of advantages can be stated:

- Adequacy: materials can be produced which are directly relevant to both students' and institutional needs, thus reflecting local content, issues and concerns.

- Expertise: material development can give the teaching board better understanding of the characteristics of effective materials and increase their expertise, contribution and confidence.

- Reputation: institutionally published teaching resources can foster the reputation and image of the higher educational institute by showing its competitive edge in providing its students with incompany produced materials.

- Adjustability: materials developed by the institution faculty can be revised, adapted or updated as needed, thus giving them greater flexibility than external published course books.

However, there are some potential drawbacks in the exploitation of teacher-derived materials:

- Cost and quality: high-quality materials prove to be time-consuming and demand greater resources to be allocated. Moreover, teacher-tailored materials can lack proper design and content to meet the needs of both international and domestic students.

- Training: it is of utmost importance to train and prepare teachers for producing high-quality and specialized materials.

In most situations, commercial materials form the basis of the curriculum in ESP programs supplemented by teacher-tailored ones which better reflect the needs of the specific learning context.

The selection of ESP materials should thus above all depend on the needs of the learners in relation to their future or present jobs: that is, "materials should focus on the appropriate topics and include tasks and activities that practise the target skills areas' [12]. Another important criterion that should be taken into account when selecting materials is the level of language knowledge students have already acquired and the target level they will need to communicate successfully in their jobs.

ESP courses, being predominantly learner-centred, make a demand on putting students' perspectives at the top of the list of selection criteria. According to Lewis and Hill students' considerations include the following aspects: 'the level of usefulness of the chosen materials, degree of curiosity to stimulate better learning, topic relevance to their needs, activities and tasks being fun to do and worth implementing in their future career' [13].

Thus, after analysing learner needs and setting objectives for the course, the ESP educator has to select materials that will help both the teacher and students 
achieve the course objectives. These materials should also relate closely to the learners' specific skills and content needs, which is an important precondition for full exploitation of the materials, as well as the learners' motivation.

Coming to the decision on whether to use readily available textbooks or tailor-made materials is primarily based on the learners' subject area. If their subject area is more general, the likelihood of finding suitable published materials is much higher. Accordingly, ESP teachers will most often select suitable materials from existing printed materials. In the case of more specific subject areas, the most widely accepted view is that ESP teachers should also first question whether the learners' needs are significantly different from those of other groups and, if possible, select from existing printed materials and resort to writing materials when all other possibilities of providing materials have been exhausted.

In case of PREU (Plekhanov Russian University of Economics), it sturdily encourages teaching staff to develop in-company produced coursebooks of English for Specific Purposes, therefore we are more likely to provide our students with tailor-made materials. It is vital also to point out that the number of institutionally developed materials for ESP in Russian higher education institutions is relatively high, due mainly to the fact that teachers here make every effort to cater for the specific needs of the professional language they teach. To meet this end, they either adapt commercial textbooks to the specific needs of the particular subject area and to the level of students' language awareness or prepare inhouse materials if no suitable printed materials are available in the market.

If a teacher resorts to using a readily available textbook, the selection of structures, vocabulary, skills, functions, and so on is conditioned by the textbook to a large extent and can be extended into other areas teachers find relevant to their students. Tailor-made materials, on the other hand, provide the teacher with the opportunity to decide on combinations of vocabulary, functions and structures and to develop materials that will introduce most relevant vocabulary and related functions and structures.

A final but significant factor is that psychologically a textbook represents something concrete and thus gives a measure of progress and achievement throughout the course. Consequently, when designing materials teachers should bear this in mind and prepare materials that present a logical whole and in which the sequence of units is logical and enables the students to see and evaluate their progress.

Based on our own teaching experience, together with colleagues from PREU, we revealed the fact that there is a lack of subject-specific textbooks for students specializing in diverse areas of Economics: Marketing and Finance, Management and Logistics, Law Studies and International Commerce, etc. Therefore, we have prepared institutionally published tailor-made coursebooks for all programs majoring in Economics. The selection of topics is dictated specifically by students' needs - relevant to the key fields of their future profession and feasible job-related requirements.
Another benefit of these tailored ESP courses is the topic authenticity, as all materials are taken from authentic up-to-date business magazines, newspapers and company websites, for example The Economist, The Guardian, CFO Magazine, Forbes, 12manage.com, mckinsey.com, businesscasestudies.co.uk, etc. and supplemented with online learning resources, as YouTube Education, BBC Learn English, British Council Learn English, etc. Moreover, we can note that the level of meeting students' expectations from the courses is much higher in using in-company produced materials, rather than existing textbooks. First of all, the choice of materials is based on the demands of employment market, secondly on the country's business environment and its specifications, and finally, on the students' needs and knowledge base. Tailor-made materials provide students with activities that suit the specific needs of their future or current jobs or, as Sheerin points out: 'In-house produced material is extremely valuable as it is inevitably more precisely geared to the needs of students than published material' [14]. When determining what tasks to include in ESP materials, teachers should thus above all strive to select and/or design tasks that will simulate the learners' reallife business situations as closely as possible.

Table 1. Paradigm shits in ESP course designs, PRUE.

\begin{tabular}{|c|c|c|c|c|}
\hline Years & Courses & Skills & $\begin{array}{c}\text { Course } \\
\text { formats }\end{array}$ & $\begin{array}{c}\text { Delivery } \\
\text { modes }\end{array}$ \\
\hline 2013 & $\begin{array}{c}\text { Professional } \\
\text { English }\end{array}$ & $\begin{array}{l}\text { Reading } \\
\text { Writing } \\
\text { Speaking }\end{array}$ & Printed & Traditional \\
\hline 2014 & $\begin{array}{c}\text { English for } \\
\text { Professional } \\
\text { Use }\end{array}$ & $\begin{array}{l}\text { Reading } \\
\text { Writing } \\
\text { Speaking } \\
\text { Listening } \\
\text { Projects }\end{array}$ & Printed & Traditional \\
\hline 2015 & $\begin{array}{l}\text { Business } \\
\text { English } \\
\text { Insights }\end{array}$ & $\begin{array}{l}\text { Reading } \\
\text { Speaking } \\
\text { Audio- } \\
\text { video } \\
\text { pack } \\
\text { Projects }\end{array}$ & $\begin{array}{l}\text { Printed / } \\
\text { Online }\end{array}$ & Blended \\
\hline 2016 & $\begin{array}{c}\text { Professional } \\
\text { Business } \\
\text { Discourse }\end{array}$ & $\begin{array}{c}\text { Reading } \\
\text { Writing } \\
\text { Speaking } \\
\text { Audio- } \\
\text { video } \\
\text { pack } \\
\text { Projects }\end{array}$ & $\begin{array}{c}\text { Printed / } \\
\text { Online }\end{array}$ & $\begin{array}{l}\text { Blended / } \\
\text { Individual }\end{array}$ \\
\hline 2017 & $\begin{array}{c}\text { Business } \\
\text { English } \\
\text { Communica } \\
\text { tion }\end{array}$ & $\begin{array}{l}\text { Reading } \\
\text { Critical } \\
\text { thinking } \\
\text { Online } \\
\text { pack } \\
\text { (Listening } \\
\text { / Writing) }\end{array}$ & $\begin{array}{l}\text { Web- } \\
\text { based }\end{array}$ & $\begin{array}{l}\text { Blended / } \\
\text { Individual }\end{array}$ \\
\hline
\end{tabular}

Above given Table 1 illustrates the paradigm shifts in institutionally produced ESP course designs from 20132017, PRUE. During the first two years, the main focus of tailored courses was on 4 key language competencies provided through printed materials and delivered mostly in-class by using traditional teaching and learning 
methods. Later, in 2015-16, in-company produced materials were released in two formats, both printed and online, they were also vastly supplemented with virtual resources. Yet, the last year of survey showed a significant shift from printed to entirely web-based learning platform based on blended learning models. So, the researched ESP electronic courses are marked by such features as fostering students' individual learning, increasing intercultural, analytical and language competences, as well as educators' academic mobility and professionalism.

Still, no matter how good these materials are, they should leave some room for flexibility and give the teacher the opportunity to respond to the needs of individual learners. At the same time they should encourage students to share their thoughts and experience because both pre-experience and certainly job experienced students are highly motivated to do so, as we meet mostly doing Bachelor's and Master's Degrees.

When designing tailor-made materials, teachers can rely on some general considerations that can also be used when deciding on the appropriate textbook. According to Haycraft, some of the most important considerations are as follows: 'the course length, target audience, useful vocabulary in current use, visually alive and wellpresented materials' [15].

Although learners can undoubtedly learn most of the needed skills, functions and to a great extent also general terminology from general business textbooks, they will undoubtedly gain even more when using in-house developed resources or a combination of a general business textbook and tailor-made materials because these two options are more likely to provide them with directly applicable knowledge.

\section{Conclusion}

An overview of ESP courses in tertiary education reveals the importance of needs analysis, the careful selection and adaptation of teaching materials which determine the overall adequacy and significance of the course design, its implementation and direct relation to the students' needs. In most cases ESP courses are taught and learned with high motivation because students regard these language skills as important means of communication for their studies and professional life.

The teaching materials, either commercially published ones or institutionally produced should mostly satisfy the students' needs for professional English, thus being authentic, interesting, various, and providing helpful and relevant specialty data. It is worth quoting here that 'a key issue when considering the choice of course book or any material is authenticity' [16].

The ESP courses should foster the use and development of functional language and productive skills. Therefore, the teaching resources after adaptation or reproduction should include tasks, techniques and content which, first, meet the requirements of learners, and secondly, are beneficial for learners in their studies and future profession.
In current internationalised and globalised business era it is quite rewarding to master such professional skills as cross-cultural competence, socializing and analytical thinking abilities, which can be fostered through in-company developed and provided learning resources.

\section{References}

1. T. Hutchinson, A. Waters, English for specific purposes. A learning-centered approach (Cambridge University Press, 1992)

2. K. Harding, English for Specific Purposes (Spain: Oxford University Press, 2007)

3. B. Klimova, Procedia - Social and Behavioral Sciences 197, 104-107 (2015)

4. M. Tzoannopoulou, Procedia - Social and Behavioral Sciences 173, 149-153 (2015)

5. Y. P. Aylazyana, O. A. Obdalovab, Procedia Social and Behavioral Sciences 154, 381-385, (2014)

6. P. Vičič, Inter Alia 2, (CC) SDUTSJ, 107-120 (2011)

7. E. T. Minasyan, Conference proceedings "Humanitarian Education at Economic University", PRUE, 116-120 (2015)

8. P. Strevens, Teaching English as an international language: form practice to principle (Oxford: Pergamon Press, 1980)

9. G. T. Benavent, S. Sánchez-Reyes, Procedia - Social and Behavioral Sciences 173, 13 143-148 (2015)

10. H. Basturkmen, Palgrave Macmillan 154, (2010)

11. R. Ellis, C. Johnson, Teaching business English (Oxford University Press, 1994)

12. K. Morrow, Techniques of evaluation for a notational syllabus (London: Royal Society of Arts, 1977)

13. M. Lewis, J. Hill, Source Book for Teaching English as a Foreign Language (Hong Kong: Macmillan Publishers Limited, 2003)

14. S. Sheerin, Resource Books for Teachers: SelfAccess (Hong Kong: Oxford University Press, 1989)

15. J. Haycraft, An Introduction to English Language Teaching (Malaysia: Longman Group Ltd., 1987)

16. Polyakov O.G., Psycho-pedagogical aspects of ESP course design: analysis of learning theory (Tambov: Gramota 12(30), 166-169 (2013) 